\title{
Learning styles of Fully Residential Schools' Students in Mathematics through the Flipped Classroom Method: Do Gender Factors Cause Different Impacts?
}

\author{
Azlina A.Rahman ${ }^{1 *}$ Norasykin Mohd Zaid ${ }^{2}$, Baharuddin Aris ${ }^{3}$, \\ Hasnah Mohamed ${ }^{4} \&$ Zaleha Abdullah ${ }^{5}$ \\ ${ }^{1}$ Sekolah Berasrama Penuh Integrasi Selandar, Melaka, Malaysia \\ 2,3,4,5 Universiti Teknologi Malaysia \\ *Corresponding Author: linskkb2012@gmail.com
}

\begin{abstract}
This study was conducted with its aim to measure the dominant learning styles of Fully Residential Schools' students. The need to acquire the dominant learning styles of these students arose since they are bound to the school environment which limits learning styles according to their inclination. Hence, individual and group learning styles were developed to fulfil the needs of the students in context of their favourite learning styles. However, there were raised concerns whether learning styles would cause different impacts, based on gender if they are integrated in Mathematics. This study gave the answer through a survey conducted on a total of 61 Fully Residential Schools' students, 31 of whom underwent the proposed intervention in the form of flipped classroom method, while the remaining 30 were in the control group. The findings of the study obtained by a descriptive analysis showed that group learning was the dominant learning style adopted by the students. In addition, the findings also showed that, there was no significant difference in learning styles based on gender. It was concluded that Fully Residential Schools' students needed group activities in their learning and their learning styles were not focused only on one particular type. Regardless of gender, they were capable of being actively involved in group activities. So this study had the potential to be implemented in the 21 st century learning which emphasizes on group activities that should integrate learning styles well in tandem with the teachers' teaching.
\end{abstract}

Keywords Learning style, mathematics, gender, Fully Residential School.

\section{INTRODUCTION}

Effective learning can be obtained based on the inclination of students' learning styles to learn through their respective learning styles [1]. Learning style is one of the ways where the students learn based on their inclination and interest in understanding their learning, while taking the surrounding factors into account [2]. These factors include learning through psychomotor movements, learning through auditory or visual learning [3]. However, the main constraint faced by students living in Fully Residential schools was that, their ability to learn relied on limited surrounding factors, in terms of a living environment which is school and dormitory-centred. This was in contrasts with those attending daily schools, whose learning styles were unlimited. This is mainly because in Fully Residential Schools, the students' learning styles are somehow influenced by the management of the school and its dormitory. Comparing the learning styles of the Fully Residential Schools or Sekolah Berasrama Penuh students with those of their peers in daily schools, the former have constraints in terms of learning style diversity. Hence, this study assessed the dominant learning styles of Fully Residential Schools' students to ascertain if they were in tandem with 
the needs of the learning style the 21 st century which required group activities. In its implementation, the individual and group learning styles were suited to the context of the study in Fully Residential School. Individual learning styles are important for Fully Residential School students as they need to learn independently during the preparation class, a daily routine for them. On the other hand, group learning styles are the preferred method in group learning. Hence both individual and group learning styles are important for Fully Residential Schools's students.

In addition, this study was also to determine if students' learning styles in Fully Residential Schools varied according to gender under the same environment. Mathematics was selected as the subject of study since it was deemed a difficult subject which often requires guidance from teachers and peers. Hence its appropriateness to be integrated into individual and group learning styles must to be reviewed to see the impacts caused through the implementation of the flipped classroom method.

Flipped classroom is a 21 st century learning which comprises both out-of-classroom learning and inthe-classroom learning [4-6], the former requiring self-learning while the latter involving group learning [7]. Thus, this study also took into account the types of learning styles which suited well with the flipped classroom method.

To find out the dominant learning styles of the respondents and to ascertain if the learning styles would cause different impacts, based on gender factor, a total of three questions were used as a guide in conducting the study as follows:

\section{Research questions:}

1. What is the dominant learning style of the 61 Form-Two Fully Residential Schools' students?

2. Are the learning styles of male and female students for Mathematics different, based on gender?

3. Are there relationships between the learning styles of the respondents in the control group and those of their peers in the intervention group?

Based on the research questions above, the required data was obtained based on the study methodology before it was analyzed.

\section{METHODOLOGY}

This study was conducted on a total of 61 students, 30 of whom were in the control group while the other 31 were in the intervention group. The study was started by finding out the dominant learning styles of all the 61 respondents using a survey method based on a learning style questionnaire consisting of individual and group constructs. The subsequent step was to implement the intervention by means of the flipped classroom method on a total 31 students in the intervention group. 


\section{FINDINGS AND DISCUSSION}

The findings from the analysis of the data obtained for the first question are shown in Table 1.

Table 1 Frequency of learning style by gender

\begin{tabular}{|c|c|c|c|c|c|c|}
\hline \multicolumn{4}{|c|}{ Respondent } & \multicolumn{2}{|c|}{ Gender } & \multirow{3}{*}{$\begin{array}{c}\text { Total } \\
11 \\
\end{array}$} \\
\hline & & & & \multirow{2}{*}{$\begin{array}{c}\text { Male } \\
4\end{array}$} & \multirow{2}{*}{$\begin{array}{c}\text { Female } \\
7\end{array}$} & \\
\hline \multirow{8}{*}{ Intervention } & \multirow{6}{*}{$\begin{array}{c}\text { Learning } \\
\text { Style }\end{array}$} & \multirow{2}{*}{ Individual (I) } & Frequency & & & \\
\hline & & & Percentage & $12.9 \%$ & $22.6 \%$ & $35.5 \%$ \\
\hline & & \multirow{2}{*}{ Group $(\mathrm{G})$} & Frequency & 7 & 12 & 19 \\
\hline & & & Percentage & $22.6 \%$ & $38.7 \%$ & $61.3 \%$ \\
\hline & & \multirow{2}{*}{ Individual and Group (IG) } & Frequency & 1 & 0 & 1 \\
\hline & & & Percentage & $3.2 \%$ & $0.0 \%$ & $3.2 \%$ \\
\hline & \multirow{2}{*}{\multicolumn{2}{|c|}{ Total }} & Frequency & 12 & 19 & 31 \\
\hline & & & Percentage & $38.7 \%$ & $61.3 \%$ & $100.0 \%$ \\
\hline \multirow{8}{*}{ Control } & \multirow{6}{*}{$\begin{array}{c}\text { Learning } \\
\text { Style }\end{array}$} & \multirow{2}{*}{ Individual (I) } & Frequency & 2 & 1 & 3 \\
\hline & & & Percentage & $6.7 \%$ & $3.3 \%$ & $10.0 \%$ \\
\hline & & \multirow{2}{*}{ Group (G) } & Frequency & 12 & 12 & 24 \\
\hline & & & Percentage & $40.0 \%$ & $40.0 \%$ & $80.0 \%$ \\
\hline & & \multirow{2}{*}{ Individual and Group (IG) } & Frequency & 1 & 2 & 3 \\
\hline & & & Percentage & $3.3 \%$ & $6.7 \%$ & $10.0 \%$ \\
\hline & \multirow{2}{*}{\multicolumn{2}{|c|}{ Total }} & Frequency & 15 & 15 & 30 \\
\hline & & & $\begin{array}{c}\text { Total } \\
\text { Percentage }\end{array}$ & $50.0 \%$ & $50.0 \%$ & $100.0 \%$ \\
\hline
\end{tabular}

Based on Table 1, it was found that the majority of male and female students from both the treatment group and the control group favoured the group learning styles at the percentages of $61.3 \%$ and $80.0 \%$, respectively. This proved that the majority of Form-Two Fully Residential Schools' students favoured the group learning styles such as student-centred learning and this answered the first question.

To answer the second question of the study, an inference analysis was conducted.

Significant tests were later carried out to examine if there were any correlation between learning styles based on gender using the following hypotheses:

\section{Null Hypothesis, Ho:}

There was no significant relationship in terms of gender-based learning style. 


\section{Alternative Hypothesis, $\mathrm{H}_{1}$ :}

There was a significant relationship in terms of gender-based learning style.

Following that, the relationships between gender-based learning styles were measured via a Chi Square test using data obtained from the two categories. The findings from the data analysis are shown in Table 2.

Table 2 Chi Square test by gender

\begin{tabular}{|l|l|l|l|}
\hline & Value & df & Asymp. Sig. (2-sided) \\
\hline Pearson Chi-Square & $.065^{\mathrm{a}}$ & 2 & .968 \\
\hline Likelihood Ratio & .064 & 2 & .968 \\
\hline Linear-by-Linear Association & .044 & 1 & .833 \\
\hline N of Valid Cases & 61 & & \\
\hline
\end{tabular}

a. 2 cells (33.3\%) have expected count less than 5. The minimum expected count is 1.77 .

Based on Table 2, the data analysis for the Chi Square test revealed that the relationships between learning styles by gender were not significant $\left[\chi^{2}(2, \mathrm{~N}=61)=0.065, \mathrm{p}>0.05\right]$. This finding indicated that neither the male nor the female students were particularly inclined to the individual or group learning styles. In other words, the male or the female students showed no difference in inclination, based on gender, and this answered the second question of the study.

The subsequent analysis was to measure the relationships in terms of learning styles between the intervention group and the control group as shown in Table 3.

Significant tests were carried using the following hypotheses to examine if there were any relationships between group-based learning styles:

\section{Null Hypothesis, Ho:}

There was no significant relationship in terms of learning styles between the control group and the intervention group.

\section{Alternative Hypothesis, $\mathrm{H}_{1}$ :}

There was a significant relationship in terms of learning styles between the control group and the intervention group.

The findings of the study to measure the relationship in terms of learning styles between groups are shown in Table 3. 
Table 3 Chi Square Test by groups

\begin{tabular}{|l|l|l|l|}
\hline & Value & df & Asymp. Sig. (2-sided) \\
\hline Pearson Chi-Square & $6.138^{\mathrm{a}}$ & 2 & .046 \\
\hline Likelihood Ratio & 6.473 & 2 & .039 \\
\hline Linear-by-Linear Association & 5.818 & 1 & .016 \\
\hline N of Valid Cases & 61 & & \\
\hline
\end{tabular}

a. 2 cells (33.3\%) have expected count less than 5. The minimum expected count is 1.97 .

Based on Table 3, the data analysis for the Chi Square Test was found to be significant $[\chi 2(2, N=61)=$ $6.138, \mathrm{p}<.05]$, indicating that there was a significant difference between the control group and the intervention group in terms of learning styles. Therefore, a correlation test namely Cramer's V Correlation Test was conducted to see the strength of the learning style relationships for the intervention group and the control group.

Table 4 Cramer's V Correlation Test

\begin{tabular}{|l|l|r|r|}
\hline \multicolumn{2}{|l|}{} & Value & Approx. Sig. \\
\hline Nominal by Nominal & Phi & .317 & .046 \\
\cline { 2 - 4 } & Cramer's V & .317 & .046 \\
\hline N of Valid Cases & 61 & \\
\hline
\end{tabular}

Based on Table 4, it was found that there was a significant relationship in learning styles between the intervention group and the control group $(\mathrm{V}=.317, \mathrm{p}<.05)$. The findings also revealed that although both the intervention and the control groups favoured group learning style $(\mathrm{G})$ compared with Individual (I), the percentage of students from the control group who favoured group learning style exceeded that of students from the intervention group. However, from the Individual (I), aspect the percentage of students from the intervention group who favoured individual learning styles was higher than that of students from the control group and this answered the third question of the study.

\section{CONCLUSION}

A conclusion can be made based on the result of the data analysis, that Fully Residential School Form Two students were inclined to group learning styles. In other words, gender factors do not cause any different impact. Hence the application of group-based activities and student-centred learning is necessary to fulfil their learning needs. It is in line with the 21st century learning that emphasizes student-centred learning through group activities. Therefore, the implementation of the flipped classroom method is timely given that the method provides space for self-learning students, so in-class learning is able to provide students with group activities during class-time sessions. In addition, flipped classroom methods also have the potential to meet the diverse needs of student learning styles in providing self-learning and student-centred 
learning. As such, this study also needs to be implemented starting from the school level with its potential to be extended to all students in Fully Residential Schools in Malaysia.

\section{ACKNOWLEDGEMENTS}

The authors would like to thank Universiti Teknologi Malaysia (UTM), Ministry of Education (MoE) Malaysia and Sekolah Berasrama Penuh Integrasi Selandar Melaka for their continuous support and encouragement in carrying out this study. This work was supported by the Research University Grant (R.J130000.7831.4F909) initiated by UTM and MoE.

\section{REFERENCES}

[1] Zappe, S., Leicht, R., Messner, J., Litzinger, T., \& Lee, H. W. (2009). Flipping the classroom to explore active learning in a large undergraduate course. American Society for Engineering Education.

[2] Lage, M. J., Platt, G. J., Treglia, M., \& Lage, J. (2000). Inverting the classroom: A gateway to creating an inclusive learning environment. J. Econ. Educ., 31(1), 30-43.

[3] Hollins, E. R. (2012). VAK learning styles and project-based learning with technology. The Intel Education Initiative.

[4] Baker, W. (2000). The classroom flip: using web course management tools too become the guide by the side. 11th International Conference on College Teaching and Learning, Jacksonville, FL.

[5] Rahman, A.R., Mohamed, H., Aris, B., \& Zaid, N. (2014). The influences of flipped classroom: a meta analysis. In 6th IEEE International Conference on Engineering Education (ICEED (pp. 24-28).

[6] Amresh, A., Carberry, A. R., \& Femiani, J. (2013). Evaluating the effectiveness of flipped classrooms for teaching CS1. In IEEE Frontiers in Education Conference (FIE) (pp. 733-735).

[7] Bergmann, J., \& Sams, A. (2009). Remixing chemistry class: two Colorado teachers make vodcast of their lectures to free up class time for hands-on activities. Learn. Lead. with Technology., 36, $22-27$. 
EDUCATUM JSMT Vol. 4 No. 2 (2017)

ISSN 2289-7070 / eISSN 2462-2451 (29-34)

https://ejournal.upsi.edu.my/journal/EDSC 